SHS Web of Conferences 12, 01004 (2014)

DOI: $10.1051 /$ shsconf/ 20141201004

C) Owned by the authors, published by EDP Sciences, 2014

\title{
Internal Market Orientation Framework as a Source of Improving Service Quality within the Malaysian Hotel Industry
}

\author{
J. Lahap ${ }^{1}$, N. Mohd Said ${ }^{2}$, K. H. C. Rose ${ }^{3}$, N. Sumarjan ${ }^{4}$, Z. Mohi ${ }^{5}$ \\ ${ }^{1,2,3}$ Faculty of Hotel \& Tourism Management, UiTM, 13500, Penang, Malaysia \\ ${ }^{4,5}$ Faculty of Hotel \& Tourism Management, UiTM, 40000, Shah Alam, Selangor, Malaysia
}

\begin{abstract}
This paper is developed as a means to discover the importance of improving service quality within the Malaysian Hotel Industry. To support that contention it was found that there are a number of methodologies or approaches that can be used to improve service delivery. Recent publications show that there is an emerging methodology sought to improve employee performance and one of the approaches are known as Internal Market Orientation. The Internal Market Orientation model consists of three dimensions and they are: i) Internal Market Intelligence Generation (IMIG), ii) Internal Communication (IC), and iii) Response to Intelligence (RTI). Despite of that this study will only highlight the third dimensions of the framework that is Response to Intelligence. A number of conclusive findings were found and it can be used to enhance employee performance and it is as well has the ability to improving the quality of service towards hotel guests. Notwithstanding, the findings of this study can be used to improve the competitive advantage of Malaysian Hotels and therefore, assisting the country to achieve competitiveness and leads to the creation of premier tourist destination in the world.
\end{abstract}

\section{Introduction}

Hospitality and Tourism industry is an important income generator to many countries, contributing at least 10 per cent of the world's GDP, employs over 255 million people worldwide and represents $8 \%$ of the global workforce [1]. In fact, the industry makes a significant contribution to the economic development of many countries, with some countries dependent on tourism as a catalyst for growth and development. This is the case in Malaysia where the tourism industry has been hosting large numbers of tourists arriving for business or holiday purposes as well as transient passengers' en-route to other destinations.

In 2013, the hospitality and tourism sector contributed MYR 65.44 billion (US\$ 20 billion) towards Malaysia's Gross Domestic Product [2]. Intense competition has been a feature of the tourism industry for some time and this has led to the development of sophisticated business operation strategies [3]. Lahap [4] noted, for example, instead of improving service and developing distinguish products that mollify the needs of their customers, hotels tend to distillate on improving revenue through increased sales, generally by lowering prices. 
The Internal Market Orientation framework was inspired by Kohli and Jaworski [5] and Narver and Slater [6] based on the concept of Market Orientation (customer perspective). Lings [7] transformed the Market Orientation (measuring external customer's satisfaction) framework into a study that assessed the Internal Market (measuring internal customers - employee's satisfaction). The author found that the framework (IMO) is highly applicable to assessing and evaluating service deliverer performance and employee satisfaction [8]. Gounaris [9] was one of the first researchers to adopt Lings' [10] construct and studied the impact of Internal Market Orientation on service firms. According to Lings and Greenly [8], studies on Internal Market Orientation, human resource management practice, employee job description, horizontal/vertical communication, working environment, and working conditions all played a crucial role in improving services.

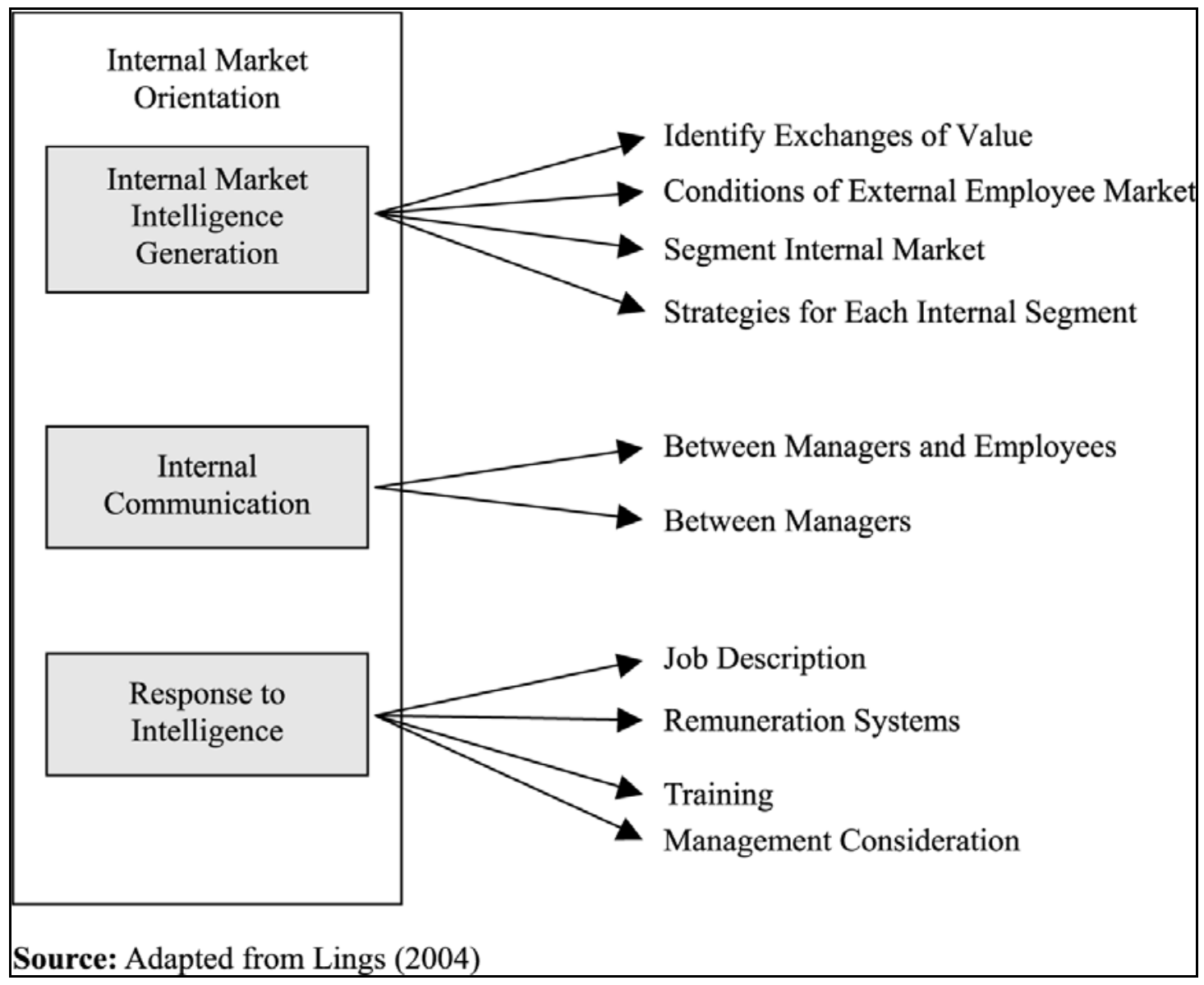

Figure 1. Internal Marketing Dimension Adapted from Lings [10]

Lings [10] described three pillars of Internal Marketing Orientation and they included: a) internal market intelligence collection, b) dissemination of intelligence, and c) responsiveness. Internal market intelligence collection relates to the identification of those issues that are valued by employees, the recognition of specific internal segments of employees with different characteristics and needs, and the design of strategies for employees (internal customers). Employee's characteristics include their personality, attitude, emotions and behaviour while their needs include all employee needs and wants required to execute their job. For example, the right tools to complete their work. These issues are important for delivering excellent service [7, 11-12]. The second pillar of Internal Market 
Orientation is dissemination of intelligence. This relates to communication between managers and employees, and communication between managers from different departments. Lings [10] further explained that the primary objectives of dissemination of intelligence are to communicate the new marketing strategy, disseminate company strategic objectives to employees, and use internal media to communicate widely (e.g. newsletters or memos). The second objective was to build an understanding of employee's needs and wants. The third pillar of Internal Market Orientation is response to intelligence; in this case, jobs are designed to meet the needs of employees. For example, adjusting compensation schemes, offering essential training for them to develop the competency to match their job description and the need for organizations to exercise what Lings [10] termed as 'management concern'. The Internal Market Orientation (IMO) construct is depicted in Figures 1 and 2.

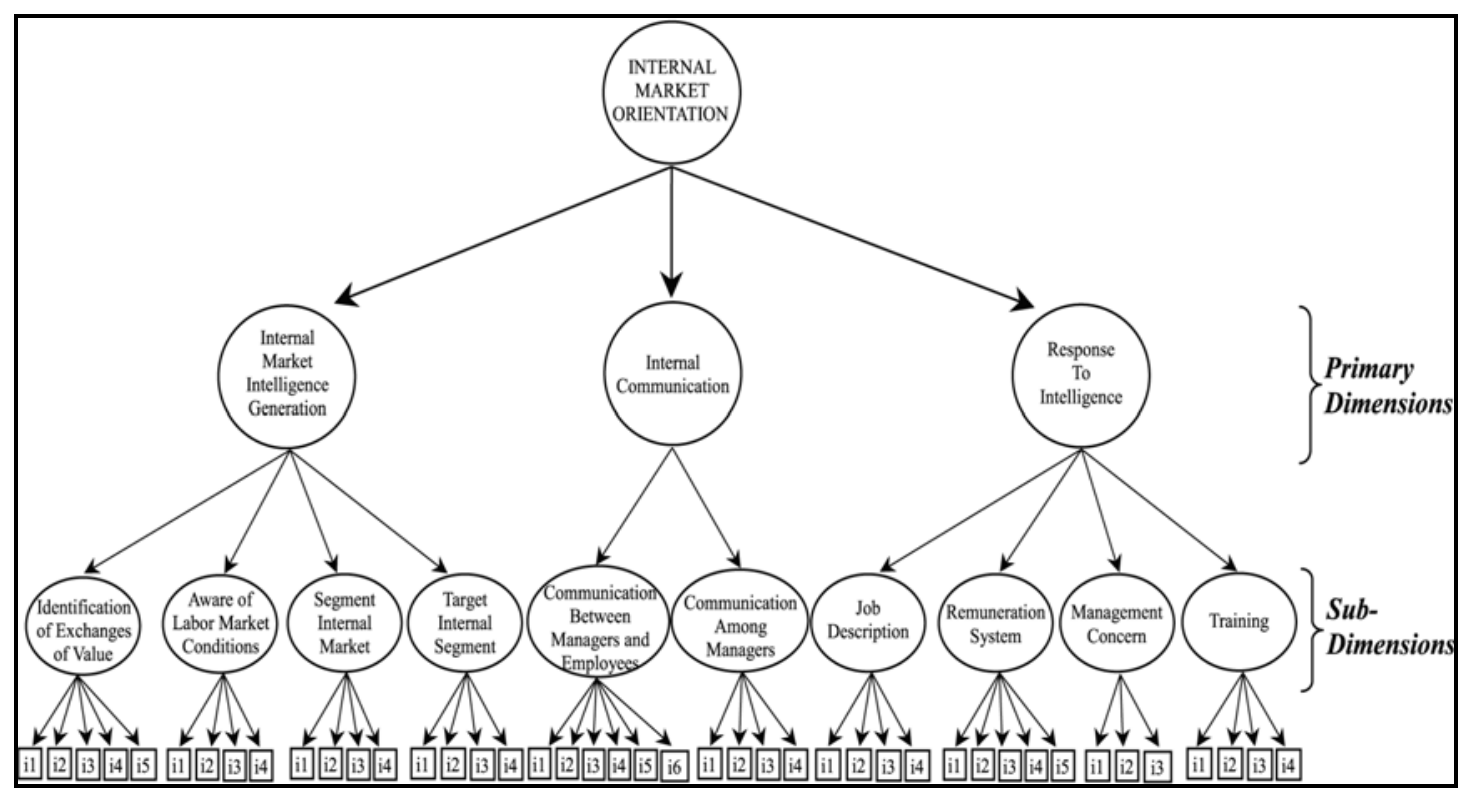

Figure 2. Internal Market Orientation Construct [9]

\section{Methodology}

In Part A, the demographic profiles of respondents is presented (gender/designation). In Part B, the Internal Market Orientation (IMO) constructs were investigated (Response to Intelligence). Twenty questions were presented to respondents using a 7 point Likert type scale adapted from Lings [10], Lings and Greenley [11] and Gounaris, [12].The Klang Valley was identified as the most appropriate geographical sampling area because the region includes the main Central Business District (CBD) of Kuala Lumpur, the capital city of Malaysia, as well as the surrounding cities Putra Jaya and Selangor. The region is also recognized as the most popular choice for business, transitory and vacation tourists with more than 10.7 million tourist visits or $41.2 \%$ of overall international tourists in Malaysia [2]. There are approximately 40-50 four and five star hotels in this region. Hence, the Klang Valley was seen to be the most appropriate geographic area for this research. Four and Five star international hotels were chosen as the target population because these establishments are recognized as having well defined management systems, organizational structures and large, well-staffed departments. The raw data underwent three different types of analyses: i) principal component analysis (PCA), ii) reliability and validity testing, and iii) the Cronbach Alpha value to assess consistency. Those methods had the capacity to identify the most important questions (or variables) of each dimension and to explain the variation between variables. Four hundreds questionnaires were distributed to four and five star hotels with 312 usable responses collected, which represents a 78\% response rate. 


\section{Data Analysis and Discussion}

By conducting cross tabulations between department and gender it was found that the front office department represents $50.3 \%$ of respondents and the food and beverage department represents $39.1 \%$ of the total respondents in the sample. In addition, there were respondents that represented departments directly related to the front office or the food and beverage department. This group of respondents constituted $10.6 \%$ of the total respondents. Overall, it was found that female respondents represented the highest percentage of respondents $(60.9 \%)$ of the overall sample. However, as the hotel industry workforce, this study in particular is dominated by female employees (Table 1). The distribution of respondents by department is presented in Tables below.

Table 1. Respondent Distribution by Departments

\begin{tabular}{|c|c|c|c|c|}
\hline \multirow{2}{*}{ Departments } & \multicolumn{2}{c|}{} & \multirow{2}{*}{ Gender } \\
\cline { 3 - 5 } & & Male & Female & \\
\hline \multirow{2}{*}{ Front Office } & 77 & 80 & 157 \\
\cline { 2 - 5 } & $\%$ & $24.7 \%$ & $25.6 \%$ & $\mathbf{5 0 . 3 \%}$ \\
\hline Food \& Beverage & & 37 & 85 & 122 \\
\cline { 2 - 5 } & $\%$ & $11.9 \%$ & $27.2 \%$ & $\mathbf{3 9 . 1 \%}$ \\
\hline Others & & 8 & 25 & 33 \\
\cline { 2 - 5 } & $\%$ & $2.6 \%$ & $8.0 \%$ & $\mathbf{1 0 . 6 \%}$ \\
\hline & & $\mathbf{1 2 2}$ & $\mathbf{1 9 0}$ & $\mathbf{1 0 0 . 0} \%$ \\
\cline { 2 - 5 } & Total & $\mathbf{3 9 . 1 \%}$ & $\mathbf{6 0 . 9} \%$ & \\
& & & & \\
\hline
\end{tabular}

Table 2. Respondents Distribution by Designation

\begin{tabular}{|c|c|c|c|}
\hline Designation & \multicolumn{2}{|c|}{ Gender } & Total \\
\hline Front Office Dept. & Male & Female & \\
\hline \multirow[t]{2}{*}{ Front Office Supervisor } & 3 & 1 & 4 \\
\hline & $1.0 \%$ & $.3 \%$ & $1.3 \%$ \\
\hline \multirow[t]{2}{*}{ Asst. F/O Supervisor } & 8 & 16 & 24 \\
\hline & $2.6 \%$ & $5.1 \%$ & $7.7 \%$ \\
\hline \multirow[t]{2}{*}{ Receptionist/Front Desk Assistant } & 13 & 29 & 42 \\
\hline & $4.2 \%$ & $9.3 \%$ & $13.5 \%$ \\
\hline \multirow[t]{2}{*}{ Telephone Operator } & 5 & 8 & 13 \\
\hline & $1.6 \%$ & $2.6 \%$ & $4.2 \%$ \\
\hline \multirow[t]{2}{*}{ Bell Captain } & 10 & 0 & 10 \\
\hline & $3.2 \%$ & $.0 \%$ & $3.2 \%$ \\
\hline \multirow[t]{2}{*}{ Bellman } & 18 & 0 & 18 \\
\hline & $5.8 \%$ & $.0 \%$ & $5.8 \%$ \\
\hline \multirow{2}{*}{ Porter } & 4 & 0 & 4 \\
\hline & $1.3 \%$ & $.0 \%$ & $1.3 \%$ \\
\hline \multirow[t]{2}{*}{ Doorman } & 5 & 0 & 5 \\
\hline & $1.6 \%$ & $.0 \%$ & $1.6 \%$ \\
\hline Total & $21.3 \%$ & $17.3 \%$ & $38.6 \%$ \\
\hline
\end{tabular}


Table 3. Respondents Designation (Food \& Beverage)

\begin{tabular}{|l|c|c|c|}
\hline \multicolumn{1}{|c|}{ Designation } & \multicolumn{2}{|c|}{ Gender } & Total \\
\hline Food \& Beverage Dept. & Male & Female & \\
\hline \multirow{2}{*}{ Food \& Beverage Supervisor } & 13 & 12 & 25 \\
\cline { 2 - 4 } & $4.2 \%$ & $3.8 \%$ & $8.0 \%$ \\
\hline \multirow{2}{*}{ Assistant Food \& Beverage Supervisor } & 5 & 14 & 19 \\
\cline { 2 - 4 } & $1.6 \%$ & $4.5 \%$ & $6.1 \%$ \\
\hline \multirow{2}{*}{ Captain } & 3 & 4 & 7 \\
\cline { 2 - 4 } & $1.0 \%$ & $1.3 \%$ & $2.2 \%$ \\
\hline \multirow{2}{*}{ Waiter/ess } & 11 & 20 & 31 \\
\cline { 2 - 4 } & $3.5 \%$ & $6.4 \%$ & $9.9 \%$ \\
\hline \multirow{2}{*}{ Bartender } & 14 & 0 & 14 \\
\cline { 2 - 4 } & $4.5 \%$ & $.0 \%$ & $4.5 \%$ \\
\hline \multirow{2}{*}{ Banquet Waiter/ess } & 0 & 29 & 29 \\
\cline { 2 - 4 } & $.0 \%$ & $9.3 \%$ & $9.3 \%$ \\
\hline Total & $\mathbf{1 4 . 8 \%}$ & $\mathbf{2 5 . 3}$ & $\mathbf{4 0 . 1 \%}$ \\
\hline
\end{tabular}

Respondents in the food and beverage department represented a total of $40.1 \%$ of the sample and waiters and waitresses from the coffee house represented $(9.9 \%)$, bartenders represented $(4.5 \%)$, and banqueting staff represented $(9.3 \%)$ of these respondents. The raw data underwent three different types of analyses and these were: i) principal component analysis (PCA), ii) reliability and validity testing and iii) the Cronbach Alpha value to assess consistency. According to Hair et al. [13], there are two possible multivariate methods which can be used to identify the importance of each dimension.

It was deemed important for multivariate analysis to be conducted in this research as a means to explore the significance among questions. The Kaiser-Meyer-Olkin value of 0.91 exceeded the recommended value of 0.6 [13] and Bartlett's Test of Sphericity is statistically significant. This shows that there is a high degree of interrelationship between the questions within Response to Intelligence (job description, remuneration system, training, management concern).

The unrotated factor solution extracted five factors with Eigenvalues greater than one. According to Table 4, these five factors account for $75.54 \%$ of the explained variance, with the first factor explaining $41.47 \%$ of the variance.

Table 4. Result of the Unrotated Factor Extraction from the 19 Questions Representing Response to Intelligence.

\begin{tabular}{|c|c|c|c|}
\hline Factor & Eigenvalues & Percentage of Variance & Cumulative Percentage \\
\hline 1 & 7.8 & 41.47 & 41.47 \\
2 & 2.0 & 10.94 & 52.41 \\
3 & 1.8 & 9.95 & 62.36 \\
4 & 1.4 & 7.51 & 69.88 \\
5 & 1.0 & 5.65 & 75.54 \\
\hline
\end{tabular}

Source: Data analysis 2013, Kaiser-Meyer-Olkin Measure of Sampling Adequacy $=0.91$, Bartlett's Test of Sphericity $=4549.159$, Significance $=0.00$

The pattern loadings, factor structure and factor interpretation are shown in Table 5 below. The dimensions were defined by the variables with factor loadings of 0.6 and above. Reliability tests on each of the factors resulted in a Cronbach Alpha coefficient above 0.91. This meant that the 19 questions were accepted (some of the initial scale items were not included in the final result because the loading values were below 0.6). 
Table 5. Reliability Cronbach's Alpha = 0.91; Source: Data analysis (2013); LD: Factor Loading; Result of Varimax rotated factor matrix for Response to Intelligence (RTI)

\begin{tabular}{|c|c|c|}
\hline \multicolumn{2}{|r|}{ Factor One } & LD \\
\hline 1. & $\begin{array}{l}\text { When I do something extraordinary I will receive some financial } \\
\text { bonus/reward }\end{array}$ & 0.77 \\
\hline 2. & Everyone gets an annual bonus regardless of their performance & 0.56 \\
\hline 3. & $\begin{array}{l}\text { My income and annual increases I receive are the same as those of } \\
\text { people with similar qualifications working in this or any other industry }\end{array}$ & 0.83 \\
\hline 4. & The senior management of this hotel understand staff problems & 0.74 \\
\hline 5. & $\begin{array}{l}\text { Senior management really considers our individual needs and makes } \\
\text { policies that reflect it }\end{array}$ & 0.78 \\
\hline 6. & $\begin{array}{l}\text { Senior management is resolved to solving our problems and giving us all } \\
\text { the required support necessary for our job }\end{array}$ & 0.65 \\
\hline \multicolumn{3}{|c|}{ Factor Two } \\
\hline 1. & $\begin{array}{l}\text { In this hotel, training is closely related to the individual needs of each } \\
\text { employee }\end{array}$ & 0.70 \\
\hline 2. & A newly hired employee will be briefed to the requirements of the job & 0.86 \\
\hline 3. & $\begin{array}{l}\text { Before any implementation of a major change in service rules, we always } \\
\text { get lots of training regarding its impact on our daily activities and job } \\
\text { description }\end{array}$ & 0.70 \\
\hline 4. & $\begin{array}{l}\text { If an employee is transferred from one department to another, the new } \\
\text { supervisor will personally train him/her for a pre-specified period of time }\end{array}$ & 0.86 \\
\hline \multicolumn{3}{|c|}{ Factor Three } \\
\hline 1. & $\begin{array}{l}\text { My job description is flexible enough for me to satisfy my personal } \\
\text { needs and goals through my work }\end{array}$ & 0.70 \\
\hline 2. & $\begin{array}{l}\text { My supervisor is expected to justify my job description and the tasks I } \\
\text { am assigned with more senior levels of management }\end{array}$ & 0.62 \\
\hline 3. & The tasks assigned to me help me to advance my career & 0.82 \\
\hline 4. & $\begin{array}{l}\text { Nothing is too expensive for our Senior Management if this would } \\
\text { satisfy specific needs of specific groups of employees in this hotel }\end{array}$ & 0.44 \\
\hline \multicolumn{3}{|c|}{ Factor Four } \\
\hline 1. & $\begin{array}{l}\text { My income and annual increases are depending on me bargaining with } \\
\text { my employer }\end{array}$ & 0.61 \\
\hline 2. & $\begin{array}{l}\text { My income and annual increases are very closely tied to my } \\
\text { qualifications }\end{array}$ & 0.83 \\
\hline 3. & My income and annual increases are very closely tied to my performance & 0.83 \\
\hline \multicolumn{3}{|c|}{$\begin{array}{l}\text { Factor Five } \\
\end{array}$} \\
\hline 1. & $\begin{array}{l}\text { Nothing has ever been assigned to me unless my supervisor and I had } \\
\text { agreed that I could really do it }\end{array}$ & 0.72 \\
\hline 2. & I never receive an annual increase & 0.84 \\
\hline
\end{tabular}

An inspection of the item loading (LD) values found that the 19 questions respondents were asked on response to intelligence were significant and interrelated to each other. Those 19 questions were regrouped into five new factors. However, there were questions that had factor loadings below the 
recommended value of 0.6 (Hair, et al. 1998). As a result, those questions were eliminated due to their low significance.

\section{Recommendations}

It can be summarized that service employees' job descriptions, the remuneration system, management concern and training are important factors to the enhancement of employee job performance [11-12]. It can be further suggested that in order to produce high quality of service, hotel employers should look after employees needs and wants as a means of enhancing job performance.As a result, based on the analysis, it can be suggested that Response to Intelligence [KMO 0.91] (job description, remuneration system, training and management concern) and its dimensions were found to be significant dimensions to the improvement of service provider performance $[4,14]$.

\section{Conclusion}

As a conclusion it can be suggested that job description, remuneration system, training and management concern was known to be significant in improving employee job performance. To support that contention Sumarjan, Arendt and Shelley [15] proposed that the involvement of top management in setting up the most appropriate organization procedure, policy and system is crucial. As a result, the quality of service delivery can be improved through special attention on the percepts of response to intelligence that was originated from Internal Market Orientation Framework. It was also advised that hotel industry in Malaysia should consider the findings to improve their service delivery holistically. Mohi, Clemes and Hu [17] posit that in improving service quality, hospitality organization was advised to adopt strategy that is align to the objective, vision and mission of a company that was developed in the earlier stage, therefore, to disseminate them to employees is imperious. This study enriches our understanding on how a service delivery can be improved through improving employee's performance. Subsequently, this paper had successfully achieved its main objective that surge to discover the dynamics that could enhance the quality of service delivery and service quality among hotel operators in Malaysia.

\section{References}

1. World Travel \& Tourism, World Travel \& Tourism Report 2012. Tourism Economic, Research.

2. Tourism Malaysia, Tourism Report, Malaysian Tourism Promotion Board 2012, Retrieved from: www.corporate.tourism.gov.com.my. 16/01/2013.

3. J. Lahap, J. Dalrymple, G. B. O'Mahony, Barriers to Improving Service Delivery in Malaysia Hotels: Experts' View on a proposed Model, 9th Annual Tourism and Hospitality Research in Ireland Conferences (THRIC) College of Tourism and Arts, Galway-Mayo Institute of Technology Dublin Ireland, 12-24, (2013)

4. J. Lahap, Developing a Service Delivery Improvement Model for the Malaysian Hotel Sector, Unpublished Ph.D Dissertation 2013, Swinburne University of Technology, Melbourne, Australia.

5. A. Kohli, B. Jaworski, Market Orientation: The Construct, Research Propositions and Managerial Implications, Marketing Science Institute Report No. 90-113 (1990) Cambridge: Massachusetts.

6. J. Narver, S. Slater, The Effect of Market Orientation on Business Profitability. Journal of Marketing, 50, 3, 20-35 (1990)

7. N.I. Lings, Internal Market Orientation Constructs and Consequences, Journal of Business Research, 57 405-413 (2004)

8. N.I. Lings, E.G. Greenley, Measuring Internal Market Orientation, Journal of Services Research, 7, 3, 290-305 (2005) 
9. S.Gounaris, Internal Market Orientation and its Measurements, Journal of Business Research, 59, 432-448 (2006)

10. N.I. Lings, E.G.J. Lahap, J. Dalrymple, G.B. O'Mahony, Barriers to Improving Service Delivery in Malaysia Hotels: Experts' View on a proposed Model, 9th Annual Tourism and Hospitality Research in Ireland Conferences (THRIC) College of Tourism and Arts, Galway-Mayo Institute of Technology Dublin Ireland, 12-14, (2013)

11. S. Gounaris, Antecedents of Internal Marketing Practice: Some Preliminary Empirical Evidence, International Journal of Service Industry Management, 19, 3, 400-434 (2008a)

12. S. Gounaris, The Notion of Internal Market Orientation and Employee Job Satisfaction: Some Preliminary Evidence, Journal of Services Marketing, 22, 1, 68- 90 (2008b)

13. J.F. Hair, R.E. Anderson, R.L. Tatham, W.C. Black, Multivariate Data Analysis, $5^{\text {th }}$ Eds (2004) Prentice Hall, Madrid.

14. J. Lahap, G. B. O'Mahony, J. Dalrymple, Improving Service Quality in Malaysian Hotels: Exploring the People Dimension, Global Business and Technology Association International Conference, Helsinki Finland, 505-512 (2013)

15. N. Sumarjan, W.S. Arendt, M. Shelley, Incongruent Quality Management Perceptions between Malaysian Hotel Managers and Employees. The Total Quality Management, 25 , 2, 124-140 (2013)

16. R.C. Huseman, D. Hatfield, Equity Theory and the Managerial Matrix. Training and Development Journal, 44, 4, 98-102 (1990)

17. Z. Mohi, M.D. Clemes, B. Hu, The Development of Service Quality Dimensions for Moderate Upscale Restaurant in Malaysia, Proceedings of the $9^{\text {th }}$ APacCHRIE Conference 2011 Hong Kong. 